\title{
Beebread from Apis mellifera and Apis dorsata. Comparative Chemical Composition and Bioactivity
}

\author{
Otilia BOBIŞ ${ }^{1}$, Daniel DEZMIREAN ${ }^{1 *}$, Liviu Al. MĂRGHITAŞ ${ }^{1}$, Victoriţa BONTA ${ }^{1}$, \\ Rodica MĂRGĂOAN ${ }^{2}$, Claudia PAŞCA ${ }^{1}$, Adriana URCAN $^{1}$ and Pushpendra SINGH BANDHARI ${ }^{3}$ \\ ${ }^{1}$ Institute of Life Science s, Department of Apiculture and Sericulture. University of Agricultural \\ Sciences and Veterinary Medicine Cluj-Napoca, Romania \\ ${ }^{2}$ Biodiversity and Bioconservation Center, University of Agricultural Sciences and Veterinary Medicine \\ Cluj-Napoca, Romania \\ ${ }^{3}$ WONDER ORGANICS, Jaipur, Raj.India. \\ * corresponding author: ddezmirean@usamvcluj.ro
}

Bulletin UASVM Animal Science and Biotechnologies 74(1)/ 2017

Print ISSN 1843-5262; Electronic ISSN 1843-536X

DOI:10.15835/buasvmcn-asb: 12620

\begin{abstract}
Beebread is a valuable bee product, both for bee nutrition and for humans. The high nutritional and bioactive properties of beebread were evaluated by chemical composition analysis of beebread from Apis mellifera and Apis dorsata. Bee bread harvested from Romania and India, were evaluated for their chemical composition. Analyses were made in APHIS Laboratory from USAMV Cluj, using validated methods for bee products. Lipids were determined by the Soxhlet extraction method, total protein content was determined by Kjehldahl method, sugar spectrum was determined by high performance liquid chromatography with refractive index detection (HPLCIR). Water content of beebread samples were situated between 11.45 and $16.46 \%$, total protein content between 16.84 and $19.19 \%$ and total lipids between 6.36 and 13.47\%. Beebread has high bioactive properties which can be expressed as antioxidant and/or antibacterial activity. Chemical composition and bioactive properties of beebread is influenced by floral origin of the pollen which the bees collect and place in combs for fermentation. Also the climatic conditions have an important role in developing different fermentation compounds, that may act as antioxidants or antibacterial agents.
\end{abstract}

Keywords: Apis mellifera, Apis dorsata, beebread, chemical composition

\section{INTRODUCTION}

Apis mellifera, the latin name of European honey bee is one of the most common and widespread species of bees worldwide (Engel, 1999). This bee specie has the tendency to produce honey and other products, for storage and consumption. The colony of Apis mellifera is composed by a single fertile female (or "queen") many sterile females or "workers”, and small proportion of fertile males or "drones". It is a domesticated insect used for production of honey and other bee products and also for pollination. Beside honey, Apis mellifera bee produce pollen, bee bread, propolis and some products of their own (secretions), with high importance for humans, like wax, royal jelly or bee venom.

The western honey bee or European honey bee is the most common of the $\sim 7-11$ species of honey bees worldwide (Engel, 1999). The species' tendency is to produce a large quantity of honey for storage over the winter. It is a colonial insect which do not survive and reproduce individually, but as part of the colony in hives, where are constructing wax combs for storing honey, beebread and brood rearing. 
Apis dorsata, or giant honey bee, is the second largest bee in the world, is found mainly in forested areas of Northern India, Nepal or even in Malaysia and Singapore. They are longer in size than Apis mellifera (17-20 mm, comparing to 5-15 $\mathrm{mm}$ ). is a wild bee, it was not domesticated until now, having an aggressive defense Apis dorsata strategies and behavior when are disturbed. Their nests are built mainly in exposed places far off the ground, like big trees, under cliff overhangs, or sometimes on buildings as single large comb in the specified open space of about $1.80 \mathrm{~m}$ long and $0.90 \mathrm{~m}$ deep. Apis dorsata migrate up to $200 \mathrm{~km}$ seasonally and may build up to 150 colonies in one giant tree. Because their nests are air open, from this bee specie, man harvest only honey, bee bread and wax.

Bee bread is a bee product made by the bees from collected flower pollen, brought into the nest (hive), mixed with own secretions, honey and let in the comb for lactic fermentation. Bee bread represents the protein source of food for larvae and young bees that produce royal jelly (Markiewicz-Żukowska et al., 2013). Bee bread have similar chemical composition as bee collected pollen, being enriched with honey, propolis or other bee substances that are fermented in the comb, making its components are more available when is used as food supplement. Bee collected pollen composition depend on the botanical origin of the flower pollen that bees collect, thus bee bread also have this characteristic. The chemical composition of beebread include proteins, lipids, sugars, minerals, vitamins, organic acids, enzymes (Chmielewski, 2006, Pătruică et al., 2008, Stanciu et al., 2009), complex B vitamins, carotenoids, aminoacids and fatty acids (Dustmann, 2007). Like bee collected pollen, bee bread have a high amount of phenolics with high antioxidant properties (Stanciu et al., 2007), due to the fact that sugars and water from honey are absorbed slowly by pollen cells, which will be afterwards in osmoric shock, eliberating the inner composition of the pollen grain, making the minerals and oligoelements, aminoacids and antioxidant substances more digerable (Dustmann, 2007).

Starting not many years ago, beebread is more and more collected by the beekeepers due to the enhanced requirement of the market. Consumers are more aware of the increased bioavailability of nutrients and bioactive compounds of bee- bread compared to bee pollen (Del-Risco et al., 2012, Fuenmayor et al., 2014), and beekeepers developed specialized materials and devices to extract beebread without destroying the comb (Wilara, 2014).

Bee bread will be used in the future, more and more as a healthy food and medicine, due to its functional properties (antioxidant properties, the ability to scavenge the reactive oxygen species, responsible for different diseases)(Nagai et al., 2004, Markiewicz-Žukowska et al., 2013, Zuluga et al., 2015), antibacterial (Abouda et al., 2011) and antiproliferative properties (MarkiewiczŽukowska et al., 2013).

It is known that chemical and implicitly biological properties of bee pollen are influenced by floral origin of the pollen gathered by the bees as raw material for bee pollen production (Jivan et al., 2011, Mărgăoan et al. 2014). As the majority of the bioactive compounds are secondary metabolites of plant origin, all plant properties (meliferous and medicinal plants) are transferred to pollen and finally in beebread. Knowing the botanical origin of the pollen that was fermented into beebread, is very important for understanding the biological properties of beebread extracts.

This aspect is not given enough importance, the existing beebread on the market is consumed as is presented, without having any of these explanations of the label.

Although different studies with chemical composition of beebread from Apis mellifera are published, few studies are known about the chemical composition of beebread from Apis dorsata bees. For this reason, the aim of this study was to determin comparatively the chemical composition and antioxidant capacity of beebread from Romania (Apis mellifera) and beebread from India (Apis dorsata).

\section{MATERIALS AND METHODS}

Chemicals. Folin-Ciocalteu reagent, gallic acid, naringenin, quercetin standards were obtained from Sigma-Aldrich (St.Louis MO, USA). All other chemicals and solvents were of ultrapure grade.

Samples. Bee bread samples were provided by Wonder Organics (India) and local beekeepers from Romania through Casa Bio Cluj-Napoca harvested in 2015-2016. Samples were kept in the freezer as fresh beebread and extracts were made in methanol from $5 \mathrm{~g}$ of each sample. For a better 
extraction of the components, beebread samples were grinded and let for 72 hours maceration in methanol at room temperature under continuous stirring and protected from light. Extracts were centrifugated and the supernatant evaporated to dryness under vacuum. The resulting extracts were weighted and dissolved in ethanol for further analys. The research has been carried out in Laboratory of Quality Control for Bee Products from USAMV Cluj.

Nutritional components. Chemical composition was determined by analyzing water content, total proteins, total lipids, sugar spectrum were made following standard methods or own developed methods for each product.

Water content was determined gravimetrically, drying $5 \mathrm{~g}$ of sample at $60^{\circ} \mathrm{C}$ until constant weight.

Sugar profile for bee bread samples was determined using high performance liquid chromatography (HPLC) with refractive index detection, following the method described in International Honey Commision Methods (http://www.ihcplatform.net/ihcmethods2009.pdf), adapted in the laboratory for this specific bee product. HPLC Shimadzu system consist of a LC- 10AD pump, DGU-14A degasser, SIL-10AV VP auto sampler, RID-10A refractive index detector, thermostatted at $30^{\circ} \mathrm{C}$ with CTO-10AS VP temperature controller of separation column (Altima Amino $100 \AA 5 \mu \mathrm{m}$, $250 \mathrm{~mm} \times 4.6 \mathrm{~mm}$ ) with a mixture of acetonitril/ water as mobile phase with $1.3 \mathrm{ml} / \mathrm{min}$ flow rate. For the quantification of main sugars, a calibration curve in the range $4-0.5 \mathrm{~g} / 100 \mathrm{~g}$, with regression coefficient of $\mathrm{R}^{2}=0.9982$ for a mixture of 9 standards (glucose, fructose, saccharose, trehalose, maltose, turanose, isomaltose, erlose, melezitose) was used. Results were expressed in $\mathrm{g} / 100 \mathrm{~g}$ DW beebread.

The content of total lipids of bee bread samples was determined using Soxhlet method (Soxtherm, Gerhardt, Germany), using an adapted method from literature (Almeida-Muradian et al., 2005).

Protein content was determined by Kjeldahl digestion, distilation and titration, following an adapted method of Lujerdean and Varga (2002). A specific amount of sample was weighted and placed in special containers and than in digestion tubes (Buchi Digesion Unit K-424 coupled with Buchi Scrubber B-414), 25 $\mathrm{ml} \mathrm{H}_{2} \mathrm{SO}_{4} 95-97 \%$ was added and 2 Kjeldahl tablets each, the digestion took place for about $1.5 \mathrm{~h}$.
Distilation was made with distilation unit Büchi, KjelFlex K-360. Every determination used $50 \mathrm{ml} \mathrm{H}_{2} \mathrm{O}$ : $90 \mathrm{ml} \mathrm{NaOH}: 60 \mathrm{ml} \mathrm{H}_{3} \mathrm{BO}_{3}$ (pH 4.65).

Bioactive compounds and antioxidant activity. Total phenolics, different classes of flavonoids and bioactivity was assessed from the beebread extracts.

Total phenolic content was determined according to Folin-Ciocalteu method (Singleton et al., 1999, modified by Meda et al., 2005). Folin Ciocalteu reagent $(2 \mathrm{ml})$ was added over $0.5 \mathrm{ml}$ beebread extract and mixed for $5 \mathrm{~min}$. After the addition of $2 \mathrm{ml}$ sodium carbonate, and 2 hours reaction time protected from light, the absorbance at $760 \mathrm{~nm}$ was measured in a Jasco UV-VIS Spectrophotometer towards a blank solution. Different concentrations of gallic acid were used for plotting the calibration curve. Results were expressed as gallic acid equivalents/g beebread sample.

Flavone/flavonol content was estimated using Dowd method (Meda et al., 2005) with alumoinium chloroide as reagent. $5 \mathrm{ml}$ of beebread extract was mixed with $5 \mathrm{ml}$ aluminium chloride (2\%). The absorbtion was read after $10 \mathrm{~min}$ on a calibration curve of quercetin, and expressed as quercetin equivalents/g sample.

Total flavonoids content was determined following a method of Almaraz-Abarca et al., (2004). $4 \mathrm{ml}$ distilled water, $0.3 \mathrm{ml}$ sodium nitrite $5 \%$ and $1 \mathrm{ml}$ beebread extract were mixed thoroughly. After $5 \mathrm{~min}, 0.3 \mathrm{ml}$ of a $10 \%$ aluminium chloride was added and one minute later, $2 \mathrm{ml}$ of $\mathrm{NaOH} 1 \mathrm{M}$. Final solution was read after $30 \mathrm{~min}$ at $510 \mathrm{~nm}$. Different concentrations of quercetin were used for calibration curve and obtained results were expressed as quercetin equivalents/g sample.

Radical scavenging activity of beebread extracts against the DPPH radical was evaluated spectrophotometricallt using the method of Brandt-Williams et al. (1995) with some modifications. $1 \mathrm{ml}$ extract was mixed with $2.5 \mathrm{ml} \mathrm{DPPH}$ solution. The absorbance was measured at 517 $\mathrm{nm}$ and radical scavenging activity was expressed as inhibition percent of sample against the DPPH radical according to the formula:

$$
\% \text { Inhibition }=\left[\left(\mathrm{A}_{\text {sample }}-\mathrm{A}_{\text {blank }}\right) / \mathrm{A}_{\text {blank }}\right] \mathrm{x} 100
$$

Total antioxidant power was evaluated using ferric/reducing antioxidant potential (FRAP) 
assay (Benzie and Strain, 1996). FRAP reagent was prepared by mixing $10 \mathrm{ml}$ of $300 \mathrm{mmol} / \mathrm{l}$ acetate buffer ( $\mathrm{pH} \mathrm{3.6)}$ with $1 \mathrm{ml}$ of $10 \mathrm{mmol} / \mathrm{l}$ TPTZ (2,4,6-tripyridyl-s-triazine) in $40 \mathrm{mmol} / \mathrm{l}$ hydrochloric acid and $1 \mathrm{ml}$ of $20 \mathrm{mmol} / \mathrm{l}$ ferric chloride solution. Reaction mixture: $10 \mu \mathrm{l}$ beebread extract, $30 \mu \mathrm{l}$ deionized water and $300 \mu \mathrm{l}$ FRAP reagent was incubated at $37^{\circ} \mathrm{C}$ and the absorbance was measured after $4 \mathrm{~min}$. A calibration curve of different concentrations of $\mathrm{FeSO}_{4}$ solution was used and the results were expressed as FRAP value $\left(\mathrm{mmolFe}^{\mathrm{II}} / \mathrm{l}\right)$.

\section{RESULTS AND DISCUSSION}

The physicochemical parameters (nutritional characteristics) are described in Table 1. Low concentration of water was measured in the samples (12.20 - 15.04\%), excepting one Apis mellifera 3 beebread having $19.46 \%$ of water. All samples were considered "fresh", without additional drying. Several factors, such as ripeness, extraction techniques, relative air humidity and botanical origin, may have influence on the amount of water in the samples. Beebread samples from India, have low amounts of water, because of the climate from where were collected (samples Apis dorsata 1 and 2) and higher amount of water for sample Apis dorsata 3, collected from rainy forest zone. Romanian beebread (Apis dorsata 1-3), have higher amounts of water, but within the average amounts of fresh beebread collected from different regions of the country (Pătruică et al., 2008, Stanciu et al., 2007, 2009).

High amounts of proteins were quantified in all samples, higher amounts in Romanian samples (Apis mellifera 1-3), compared to Indian beebread. It is expected that the protein content of beebread to be similar with bee pollen, but previous studies on different bee pollen protein analysis, was highly variable, depending on the floral source of the pollen and implicitly the period of collection. Our observations were that spring pollen have higher amounts of proteins compared to summer pollen, so it is very important for beebread to register

Tab. 1. Nutritional characteristics (mean \pm S.D. in \%) of beebread from Apis mellifera and Apis dorsata

\begin{tabular}{ccccc}
\hline $\begin{array}{c}\text { Bee specie that } \\
\text { produced beebread }\end{array}$ & Water content (\%) & Dry weight(\%) & Total proteins (\%) & Total lipids (\%) \\
\hline Apis mellifera 1 & $14.14 \pm 2.3 \mathrm{c}$ & $85.86 \pm 0.85 \mathrm{c}$ & $17.19 \pm 2.1 \mathrm{~b}$ & $13.47 \pm 0.8 \mathrm{a}$ \\
\hline Apis mellifera 2 & $13.95 \pm 1.9 \mathrm{~cd}$ & $86.05 \pm 0.23 \mathrm{~b}$ & $19.19 \pm 1.9 \mathrm{a}$ & $9.69 \pm 0.5 \mathrm{c}$ \\
\hline Apis mellifera 3 & $19.46 \pm 2.1 \mathrm{a}$ & $80.54 \pm 0.64 \mathrm{e}$ & $19.10 \pm 1.7 \mathrm{a}$ & $6.36 \pm 1.1 \mathrm{e}$ \\
\hline Apis dorsata 1 & $12.25 \pm 2.0 \mathrm{e}$ & $87.75 \pm 0.26 \mathrm{a}$ & $16.86 \pm 0.9 \mathrm{c}$ & $8.93 \pm 0.5 \mathrm{~cd}$ \\
\hline Apis dorsata 2 & $12.20 \pm 1.8 \mathrm{e}$ & $87.80 \pm 0.33 \mathrm{a}$ & $17.19 \pm 2.0 \mathrm{~b}$ & $11.88 \pm 1.7 \mathrm{~b}$ \\
\hline Apis dorsata 3 & $15.04 \pm 1.9 \mathrm{~b}$ & $84.96 \pm 1.10 \mathrm{~cd}$ & $17.45 \pm 1.6 \mathrm{~b}$ & $12.02 \pm 0.9 \mathrm{~b}$ \\
\hline
\end{tabular}

Different letters in the same column are significantly different $(\mathrm{p}<0.05)$, using ANOVA, multiple comparison Duncan test.

Tab. 2. Sugar spectrum (mean \pm S.D. in \%) of bee bread from Apis mellifera and Apis dorsata

\begin{tabular}{cccccc}
\hline $\begin{array}{c}\text { Bee specie that } \\
\text { produced beebread }\end{array}$ & $\begin{array}{c}\text { Fructose } \\
(\%)\end{array}$ & $\begin{array}{c}\text { Glucose } \\
(\%)\end{array}$ & $\begin{array}{c}\text { Turanose } \\
(\%)\end{array}$ & Maltose (\%) & $\begin{array}{c}\text { Isomaltose } \\
(\%)\end{array}$ \\
\hline Apis mellifera 1 & $19.99 \pm 1.31 \mathrm{~b}$ & $12.56 \pm 1.43 \mathrm{~b}$ & $0.31 \pm 0.002 \mathrm{c}$ & $0.50 \pm 0.003 \mathrm{c}$ & $0.80 \pm 0.010 \mathrm{a}$ \\
\hline Apis mellifera 2 & $19.26 \pm 1.28 \mathrm{bc}$ & $13.48 \pm 0.96 \mathrm{a}$ & $0.66 \pm 0.001 \mathrm{a}$ & $0.59 \pm 0.004 \mathrm{~b}$ & $0.44 \pm 0.002 \mathrm{~d}$ \\
\hline Apis mellifera 3 & $16.22 \pm 0.95 \mathrm{~d}$ & $6.57 \pm 0.64 \mathrm{~d}$ & $0.61 \pm 0.003 \mathrm{ab}$ & $0.69 \pm 0.013 \mathrm{a}$ & - \\
\hline Apis dorsata 1 & $18.12 \pm 1.31 \mathrm{c}$ & $8.77 \pm 0.26 \mathrm{c}$ & $0.58 \pm 0.001 \mathrm{~b}$ & $0.37 \pm 0.001 \mathrm{e}$ & - \\
\hline Apis dorsata 2 & $20.71 \pm 1.42 \mathrm{a}$ & $13.04 \pm 1.23 \mathrm{a}$ & $0.35 \pm 0.001 \mathrm{c}$ & $0.50 \pm 0.002 \mathrm{c}$ & $0.76 \pm 0.012 \mathrm{~b}$ \\
\hline Apis dorsata 3 & $19.37 \pm 2.02 \mathrm{bc}$ & $12.62 \pm 2.12 \mathrm{~b}$ & $0.59 \pm 0.012 \mathrm{~b}$ & $0.46 \pm 0.004 \mathrm{~d}$ & $0.53 \pm 0.004 \mathrm{c}$ \\
\hline
\end{tabular}

Different letters in the same column are significantly different $(\mathrm{p}<0.05)$, using ANOVA, multiple comparison Duncan test. 
the exact period of collection and the analysis of botanical origin. Similar content was obtained by different authors (Andrada and Telleria, 2005, Somerville and Nicol, 2006, Carpes et al., 2009). Lipid content in the analyzed samples was high (6.36 \% - 13.47\%), higher compared to other Romanian beebread samples (Stanciu et al., 2009), or other type of beebread samples over the world (Fuenmayor et al., 2014, Zuluaga et al., 2015).

Sugar spectrum registered for all bee bread samples is presented in Table 2 .

Fructose was the major monosaccharide quantified in all samples, with values ranging from $16.22 \%$ to $20.71 \%$, followed by glucose (6.57-13.48\%), representing more than $50 \%$ of the total sugar content. No sucrose was present in the samples, which reflect its total hydrolization in fructose and glucose. Turanose and maltose were quantified in all samples in small amounts $(0.31$ $-0.66 \%$ and $0.37-0.69 \%$ respectively). Isomaltose was identified in 2 of the 3 samples from Apis mellifera and Apis dorsata, in higher amounts than turanose and maltose $(0.44-0.80 \%)$.

Figure 1 represents the sugar chromatogram of one beebread sample from Romania.

Beebread is a mixture of bee pollens, honey, propolis, enzymes from bee saliva, subjected to a lactic fermentation in the combs. For this reason its composition and biochemical constituents is connected to the vegetal species of pollen and nectar contributing to the complex mixture (Table 3).

Total polyphenols in the analyzed samples ranged between 19.72 and $28.61 \mathrm{mgGAE} / \mathrm{g}$ beebread. Higher amounts were quantified in beebread samples from India (Apis dorsata). Previous reports (Stanciu et al., 2009, Fuenmayor

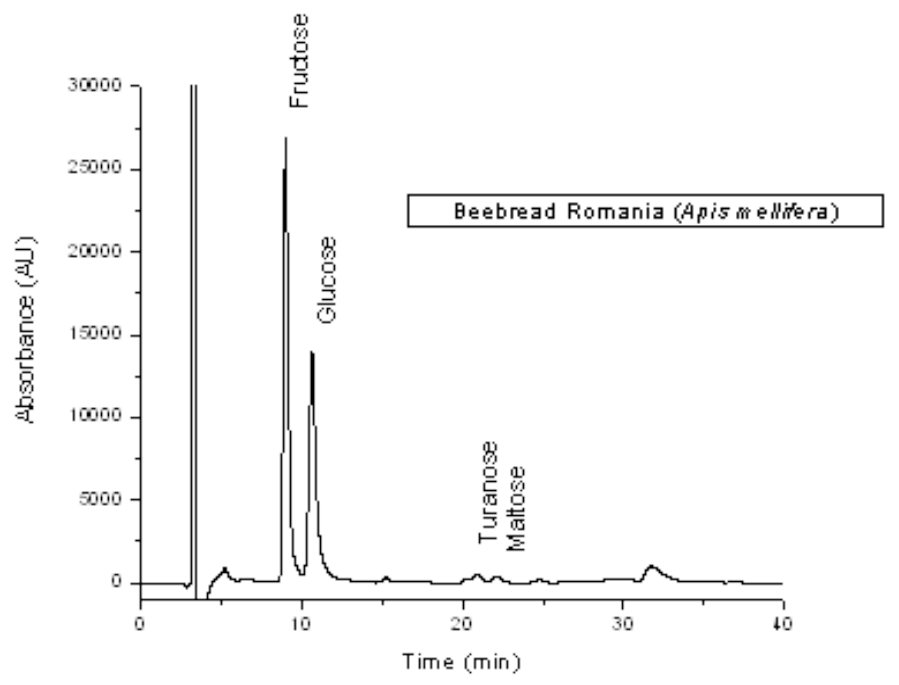

Fig. 1. Sugar chromatogram of one sample of beebread from Apis mellifera. Identified compounds were fructose, glucose, turanose and maltose.

Tab. 3. Bioactive compounds (mean \pm S.D.) of beebread from Apis mellifera and Apis dorsata

\begin{tabular}{cccc}
\hline $\begin{array}{c}\text { Bee specie that } \\
\text { produced beebread }\end{array}$ & $\begin{array}{c}\text { Total polyphenols } \\
\text { (mg GAE/g) }\end{array}$ & $\begin{array}{c}\text { Flavone/flavonols } \\
(\mathrm{mg} \mathrm{QE} / \mathrm{g})\end{array}$ & $\begin{array}{c}\text { Flavanones/dihydroflavonols } \\
\text { (mg NAE/g) }\end{array}$ \\
\hline Apis mellifera 1 & $22.72 \pm 0.2 \mathrm{e}$ & $0.69 \pm 0.02 \mathrm{~d}$ & $7.86 \pm 1.2 \mathrm{f}$ \\
\hline Apis mellifera 2 & $24.02 \pm 0.7 \mathrm{~d}$ & $0.98 \pm 0.01 \mathrm{ab}$ & $9.64 \pm 2.2 \mathrm{~d}$ \\
\hline Apis mellifera 3 & $19.72 \pm 1.2 \mathrm{f}$ & $0.66 \pm 0.00 \mathrm{e}$ & $8.65 \pm 2.5 \mathrm{e}$ \\
\hline Apis dorsata 1 & $26.42 \pm 1.2 \mathrm{bc}$ & $0.89 \pm 0.02 \mathrm{c}$ & $11.72 \pm 3.2 \mathrm{~b}$ \\
\hline Apis dorsata 2 & $28.61 \pm 1.4 \mathrm{a}$ & $0.96 \pm 0.02 \mathrm{~b}$ & $10.66 \pm 1.1 \mathrm{c}$ \\
\hline Apis dorsata 3 & $27.26 \pm 0.9 \mathrm{~b}$ & $1.09 \pm 0.00 \mathrm{a}$ & $12.64 \pm 1.9 \mathrm{a}$ \\
\hline
\end{tabular}

Different letters in the same column are significantly different $(\mathrm{p}<0.05)$, using ANOVA, multiple comparison Duncan test. 
Tab. 4. Antioxidant activity (mean \pm S.D.) of beebread from Apis mellifera and Apis dorsata

\begin{tabular}{ccc}
\hline $\begin{array}{c}\text { Bee specie that } \\
\text { produced beebread }\end{array}$ & Inhibition $\%$ & FRAP value $(\mathrm{mmol} \mathrm{Fe} / \mathrm{L})^{\mathrm{II}}$ \\
\hline Apis mellifera & $82.2 \pm 2.2$ & $0.46 \pm 0.02$ \\
\hline Apis mellifera & $79.0 \pm 2.7$ & $0.38 \pm 0.01$ \\
\hline Apis mellifera & $76.7 \pm 1.2$ & $0.42 \pm 0.03$ \\
\hline Apis dorsata & $86.2 \pm 2.2$ & $0.69 \pm 0.10$ \\
\hline Apis dorsata & $90.6 \pm 4.4$ & $0.98 \pm 0.12$ \\
\hline Apis dorsata & $87.6 \pm 3.9$ & $1.02 \pm 0.46$ \\
\hline
\end{tabular}

et al., 2014, Zuluaga et al., 2015) quantified smaller amounts of total polyphenols in bee pollen and beebread, but as stated before, very important characteristic in determining the polyphenolic composition is the botanical origin of the samples.

Flavonoid content of pollen and beebread is very important in determining the bioactive properties of the products, knowing the fact that this class of chemical compounds have antioxidant, antibacterial, immunomodulating , anti-inflammatory properties.

For the best of our knowledge is the first published study of a comparison between these two type of beebread samples regarding their bioactive constituents composition. High amountys of flavanone/dihydroflavonols were quantified in beebread samples from India (8.65 - $11.72 \mathrm{mgNAE} / \mathrm{g}$ sample). Small amounts of flavone/flavonols were also quantified in the samples.

Generally, these compounds influence the visual appearance of the grain (pigmentation) and flavour (astringency and bitterness)(Damintoti et al., 2005, DeGrandi-Hoffman et al., 2013), higher value were obtain in beebread than in bee pollen, due to possible differences in botanical origin of pollen and also the fact that a degradation of the outer layer of the grain makes more available bioactive compounds to degraded by environmental conditions. Phenolic compounds in general and flavonoids are considered among the largest contributors to the antioxidant potential of natural food products and bee products as well (Larson, 1988).

The antioxidant activity of polyphenols from bee products is due to their redox properties, which play an important role in scavenging free radicals and other oxygen species or decomposing different peroxides (Nijveldt et al., 2001). The main and most used in vitro approach for assessing the antioxidant activity of a sample is the determination of its ability to neutralize or scavenge free radicals, since anti-radical activities are very important in preventing spoilage of foods and biological systems (Gülcin et al., 2007). In this study, two techniques were used for estimating antioxidant activity under this approach: DPPH assay, which is based on the ability of a sample to scavenge the free radicals by discoloration of the DPPH radical and FRAP assay based on the reaction of ferric radical complex-2,4,6-tripyridyl-s-triazine, a relatively stable free radical capable of accepting an electron or hydrogen radical to become a stable molecule and therefore gets reduced in the presence of an antioxidant (Table 4).

In our study, DPPH discoloration, measured as inhibition percent ranged between $76.7 \%$ and 90.6\%, higher values being registered for Apis dorsata beebread samples. FRAP reported values ranged from 0.38 to 1.02 mmols $\mathrm{Fe}^{\mathrm{II}} / \mathrm{L}$.

\section{CONCLUSION}

Physicochemical and functional characteristics of bee-bread from Romania and India, produced by Apis mellifera and Apis dorsata bees, could play an important role for quality control of this product. Moderate amounts of simple sugars (fructose and glucose) make from bee bread an important bee product, highly digerable and as different scientific studies show, a very good natural food supplement. High levels of protein and lipids were found in analysis, an appreciable content of bioactive compounds indicate also 
the possibility of using bee-bread as a dietary supplement. Higher values for all parameters were quantified from bee bread and bee bread extracts from Apis dorsata bees. This is explained by the multitude of botanical species present in areas where Apis dorsata bee bread was harvested. India is well known for its medicinal (Ayurvedic) and also meliferous plants with tremendous bioactive properties.

Acknowledgments. Financial support was granted by the project Partnerships in Priority Areas Programme - PN II, developed with the support of MEN - UEFISCDI, project no. 148/2014 and RoBeeTech (grant POS CCE 206/20.07.2010 SMIS code 618/12460. The authors declare no conflict of interests.

\section{REFERENCES}

1. Almaraz-Abarca N, Campos M, Avila-Reyes J, NaranjoJimenez N, Herrera-Corral J, Gonzalez-Valdez L (2004). Variability of antioxidant activity among honeybeecollected pollen of different botanical origin. Interciencia 29:1-12.

2. Almeida-Muradian LB, Pamplona LC, Coimbra S, Barth OM (2005). Chemical composition and botanical evaluation of dried bee pollen pellets. J Food Comp Anal 18(1):105-111.

3. Andrada AC, Telleria MC, (2005. Pollen collected by honey bees (Apis mellifera L.) from south of Caldén district (Argentina): botanical origin and protein content. Grana, 44, 115-122.

4. Benzie IFF, Strain JJ (1996). The Ferric Reducing Ability of plasma (FRAP) as a measure of "Antioxidant Power": The FRAP assay. Anal Biochem 239:70-76.

5. Brandt-Williams W, Cuvelier ME, Berset C, (1995). Use of freee radical method to evaluate antioxidant activity. Lebensm. Wissench. Technol. 28:26-30.

6. Carpes ST, Cabral, ISR, Luz CFP, Capeletti JP, Alencar SM, Masson ML (2009, Palynological and physicochemical characterization of Apis mellifera L., bee pollen in the southern region of Brazil, J Food Agric Environm, 7(3,4), 667-673

7. Chmielewski W (2006). Insect and mite pest infesting and contaminating bee bread and pollen loads. In: Second European Conference of Apidology EurBee. Bee Research Institute Dol. CZ, Prtague, 103-104.

8. Damintoti K, Mamoudou H, Simpore J, Traore A, (2005). Antioxidant and antibactgerial activities of polyphenols from ethnomedicinal plants of Burkina Faso. African J Biotechnol. 4, 823-828.

9. DeGrandi-Hoffman G, Eckholm B, Huang M, (2013). A comparison of bee breawd made by Africanized and European honey bees (Apis mellifera) and its effects on hemolimph protein titres, Apidologie, 44, 52-63.
10. Del Risco C, Pérez A, Álvarez V, Rodríguez G, Leiva V, Puig Y, Garciá R (2012). Lactic acid bacteria to silage bee pollen Rev CENIC Ciencias Biológicas 43:17-21.

11. Dustmann J (2007). Fresh pollen offers best therapeutic and nutritional benefits. In $5^{\text {th }}$ German Apitherapy Congress. Passau, Gerrmany

12. Engel MS (1999). The taxonomy of recent and fossil honey bees (Hymenoptera: Apidae: Apis). J Hymenopt Res 8:165-196.

13. Fuenmayor C, Zuluga C, Diaz C, Quicazán M, Cosio M, Mannino S (2014). Evaluation of the physicochemical and functional properties of Colombian bee pollen. Rev MVZ Cordoba 19:4003-4014.

14. Gülcin I, Elias R, Gepdiremen A, Boyer L, Koksal E, (2007). A comparative study on the antioxidant activity of fringe tree (Chionanthus virginicus L.) extracts. African J Biotechnol. 6, 410-418.

15. Jivan A, Pătruică S, Jivan A (2011). Establishing some qualitative connections at the pollen collected by bees and produced by spontaneous flora in different moments of the day. Scientific Papers: Anim Sci Biotechnol 43(2):263267.

16. Larson R, (1988). The antioxidants of higher plants, Phytochem. 27, 969-978.

17. Lujerdean A, Varga A (2002). Metode şi tehnici de laborator în biochimie. Ed. AcademicPress, Cluj-Napoca

18. Mărgăoan R, Mărghitaş LA, Dezmirean DS, Dulf FV, Bunea A, Socaci AS, Bobiş O (2014). Predominant and secondary pollen botanical origin influence the carotenoid and fatty acid profile in fresh honeybee-collected pollen. J Agric Food Chem 62:6306-6316.

19. Markiewicz-Żukowska R, Naliwajko SK, Bartosiuk E, Moskwaidorov VJ, Isidorov V, Soroczyńska J, Borawska MH (2013). Chemical composition and antioxidant activity of beebread, and its influence on the glioblastoma cell line (u87mg). J Apic Sci 57(2):147-157.

20. Meda A, Lamien CE, Romito M, Millogo J, Nacoulma OG (2005). Determination of total phenolic, flavonoid and proline content in Burkina Fasan honey, as well as their radical scavenging activity. Food Chem 91:571-577.

21. Nagai T, Nagashima T, Myoda T, Inoue R (2004). Preparation and functional properties of extracts from bee bread. Food Nahrung 48:226-229.

22. Nijveldt R, Nood E, Hoorn D, Boelens P, Norren K, Leeuwen P, (2001). Flavonoids: A review of probable mechanisms of action and potential applications. Am J Clin Nutr, 74, 418-425.

23. Pătruică S, Jivan A, Hărmănescu M (2008). Researches regarding the mineral content of pollen and bee bread samples rise from Banat area. Bull USAMV-CN, 65:447.

24. Singleton V, Orthofer R, Lamuela-Raventos R (1999). Analysis of total phenols and other oxidation substratea and antioxidants by means of Folin-Ciocalteu reagent. Methods Enzymol 299:152-178.

25. Somerville DC, Nicol HI, (2006). Crude protein and amino acid composition of honey bee collected pollen pellets from south-est Australia and note on laboratory disparity. Austral J Experim Agric 46(1), 141-149. 
26. Stanciu OG, Mărghitaş LA, Dezmirean D (2009). Macro-and oligo-mineral elements from honeybee-collected pollen and beebread harvested from Transylvania (Romania). Bull UASVM AnimSci Biotechnol 66:1-2.

27. Stanciu OG, Mărghitaş LA, Dezmirean DS (2007). Examination of antioxidant capacity of beebread extracts by different complementary assays. Bull USAMV-CN 63(12):204-207.

28. Wilara (2014). Threshing and buying-in bee bread, www. wilara.it

29. Zuluga CM, Serrato JC, Quicazan MC (2015). Chemical. Nutritional and bioactive characterization of Colombian bee-bread. Chem Eng Trans 43:175-180. 